This is the final draft of an article published in Kantian Review 16 (3): 325-349. Please cite the published version, available at

http://journals.cambridge.org/action/displayAbstract?fromPage=online\&aid=8390918\&fulltextType=RA\&fileId=S1 369415411000185 , which differs in the standard ways (formatting, pagination, small grammatical corrections, etc.) from the draft.

\title{
SENSIBILISM, PsYCHOLOGISM, AND KANT's DEBT TO HUME ${ }^{\dagger}$ \\ Brian A. Chance \\ University of Oklahoma
}

There is a familiar story about Kant's relationship to Hume. According to it, Hume's account of causation presented Kant with a challenge. Hume denied the a priori origin of the concept of cause and so the a priori justification of all causal judgments. And Kant responded to a generalized version of these denials in the Metaphysical and Transcendental Deductions of the first Critique by determining the number and establishing the objective validity of the pure concepts of the understanding. The familiar story thus makes Hume's philosophy into a cautionary tale for Kant, one whose main service to was demonstrate the urgency of providing the arguments of the Transcendental Analytic and whose moral is that the use of exclusively empirical principles to explain human cognition leads invariably to skepticism. Aspects of this story are as old as the Critique itself. ${ }^{1}$ It was promulgated by the first generation of German philosophers writing in Kant's wake. ${ }^{2}$ And it quickly found its way into historical treatments of philosophy in the late eighteenth and nineteenth century. ${ }^{3}$ More recently, Paul Guyer and Michael Forster have both argued that refuting Humean skepticism is the organizing theme of the Transcendental Analytic. ${ }^{4}$

But there is also a second story, not nearly as familiar but equally old and equally important. According to it, Kant and Hume have much more in common than their well-known disagreement over the status of causal judgments would suggest. Each is critical of rationalist attempts to cognize supersensible objects such as God and the soul, and each develops his account of cognition, in part, to demonstrate the futility of these attempts. J. G. Hamann recognized this affinity with Hume in 1781 when he wrote to Herder that Kant's critique of 
speculative theology had earned him the title of a 'Prussian Hume'. ${ }^{5}$ And nearly two hundred years later, it was Hamann's comment that inspired Lewis White Beck to argue that Hume might well be thought of as a 'Scottish Kant'. ${ }^{6}$ More recently, Manfred Kuehn, Gary Hatfield, and Eric Watkins have each expanded on Hamann's suggestion, arguing that Kant viewed Hume's philosophy as a forerunner to his own critique of metaphysics. ${ }^{7}$

But the most forceful, detailed, and radical defense of this second story is the one given by Wayne Waxman in his 2005 book Kant and the Empiricists. ${ }^{8}$ Like Hamann and others, Waxman emphasizes that demonstrating the limitations of rationalist accounts of cognition (including rationalist views about cognition of supersensible objects) is important to both Kant and Hume. But on his view, the affinities between Kant and Hume run far deeper than this. For it is only Hume's failure to consider the possibility of a priori sensible intuition that Waxman believes kept him from developing two views we today regard as quintessentially Kantian: transcendental idealism and a synthetic a priori account of causal and mathematical judgments. ${ }^{9}$ Thus, on Waxman's view, it is Kant's incorporation of the a priori intuitions of space and time that has created the illusion of radical discontinuity between Kant and Hume where there is in fact great and hitherto unnoticed continuity. ${ }^{10}$

Waxman's justification of this new and provocative account of Kant's relationship to Hume relies crucially on claims about Hume's influence on Kant and, conversely, Kant's debt to Hume. ${ }^{11}$ In particular, Waxman thinks that Kant quite consciously adopted two doctrines from Hume that, when combined with his account of a priori intuition, allowed him to undermine rationalist claims to cognition of supersensible objects while at the same time providing a Humean solution to the problem of necessary connection between distinct existences that 
Waxman believes lies at the heart of Hume's views on causation. ${ }^{12}$ Waxman calls these two doctrines sensibilism and psychologism. I will return to them shortly.

To be sure, Kant's affinities with Hume have been neglected. But I believe Waxman's reading of them should be resisted. After elaborating on Waxman's conception of sensibilism and psychologism and developing criticisms of his claim that each is an instance of Kant's debt to Hume in section one, I introduce my own, more modest proposal about Kant's debt to Hume in section two and discuss the limits of Kant's debt in section three. As I hope to show in these last two sections, Kant credited Hume with being the first to argue that an analysis of the mind and the sources of its representations can yield strong arguments against rationalist claims to cognition of supersensible objects and regarded this analysis as an important (albeit a fundamentally flawed) forerunner of his arguments in the Critique. In discussing the extent to which I believe it is and is not appropriate to regard Kant as a 'Prussian Hume', I also hope to provide at least a partial explanation for the consistent appeal of the two very different stories I have just sketched.

\section{Sensibilism and Psychologism: WaXman on Kant's DebT to Hume}

Sensibilism, according to Waxman's initial formulation, is the thesis that all mental representations (perceptions in Hume's case) 'originate in (are coeval with) being perceived, and have no existence prior to or independently of their immediate presence to consciousness in perception'. ${ }^{13}$ But while this formulation may suggest that sensibilism is merely a thesis about the origin and existence of mental representations as such, Waxman makes clear that it is alsoperhaps even fundamentally - a thesis about the content of these representations. ${ }^{14}$ Sensibilism is thus the view (a) that what all representations are representations of is either the objects of 
immediate perception or the products of the mind's operations on those objects and (b) that neither these representations nor their contents have any existence 'prior to or independently of' their immediate presence to the conscious mind.

Further, Waxman emphasizes that the perception in which the sensibilist believes all mental representations and their contents originate and on which their existence depends is not limited to sensations (visual, tactile, auditory, olfactory, or gustatory) but includes the mind's perception of its own representational activity. Following a suggestion by Locke, Waxman calls this latter perception internal sense. ${ }^{15}$ And it is the inclusion of the objects of internal sense among the contents of sense that allows the sensibilist to account for our possession of concepts such as 'substance, cause and effect, space, time, magnitude, [and] real existence' without appeal to innate ideas or to some other form of what Waxman calls intellectualism. ${ }^{16}$

These objects, which Waxman (this time following Locke and Hume) calls reflexions, fall into one of four basic types. ${ }^{17}$ First, there are 'fleetingly existent perceptions [...] continually coursing through our consciousness' such as sensations and thoughts. ${ }^{18}$ Second, there are those of the former type that are specific to internal sense in the way that color is specific to vision or hearing to sound, such as 'passions, emotions, and desires'. Third, and most importantly, are representations of the mind's operations on what Waxman calls the 'data of sense', which include both sensations and reflexions. Thus, the objects of internal sense include representations of the mind's operations on what is present immediately in sense, such as the visual and tactile sensations I might perceive as the contours of a book, as well as of its operations on the products of lower-level operations (e.g. my previous perception), such as the judgment that another book is smoother or of a more piercing blue than the first. Finally, the objects of inner sense also include the objects present to us 'in and through the operations of 
thought', that is, all of the products of the mind's operations either on its own products or on what is present immediately in sense. Supplemented by this account of internal sense, sensibilism is thus the thesis that all our mental representations and their contents arise in one of two ways. Either they are given immediately in sensation or internal sense, or they are constructed by the mind's operations on the objects of sense, including, of course, representations of our momentary sensations.

Psychologism, as Waxman describes it, is a method employed by some (but not all) sensibilists. ${ }^{19}$ More specifically, it is 'the sensibilist endeavor to trace concepts at the heart of age-old philosophical disputes to their origins as ideas [what I am calling representations] in sensation and reflexion, with an eye to determining whether the operations of the mind given in internal sense make any essential contribution to their content'. ${ }^{20}$ Further, when it is determined that the content of a particular representation is due to the mind's operations on the data of sense, psychologism endorses limiting the use of that representation 'to the purview of the experiencing mind' in the same sense that, e.g. our representation of 'pleasures and pains', as subjective contents, are so limited. ${ }^{21}$ The psychologizer is thus committed to a substantive view about the proper use of mental representations whose content is the result of the operations of the mind on the objects of internal sense described in the previous paragraph. In particular, she is committed to the view that a representation cannot be legitimately used to refer to anything mindindependent if the operations of the mind have made any contribution (however minimal) to its content. Call such representations psychologically tainted. Armed with this neologism, we can elaborate on the commitments of psychologism as follows. Psychologism holds that the use of psychologically tainted representations to represent objective states of affairs in the world is illegitimate for the same reason that we all naturally believe it is illegitimate to use any 
essentially subjective concept, such as pain or joy, in contexts that abstract from its subjective content. Both involve the application of a representation whose content is essentially minddependent to something that is essentially mind-independent. Thus, if Hume is correct that the content of our concept of necessary connection is nothing more than the "customary transition of the imagination from one object to its usual attendant', the psychologistic conclusion is that any application of this concept to mind-independent objects or states of affairs (such as the impact of two billiard balls) is just as illegitimate as claims about 'unfelt pain, joy, or hate' ${ }^{22}$

With these details in mind, we can elaborate on Waxman's account of Kant's debt to Hume as follows. Kant adopts sensibilism and psychologism sometime in the 1770's after rejecting his previous account of the real use of the intellect articulated in the Inaugural Dissertation, and he credits Hume with having influenced his own views in numerous passages from the critical works. ${ }^{23}$ In the context of the Critique, this influence is felt primarily in the Transcendental Aesthetic and the Analytic of Concepts, where the status of space, time, and the categories as representations in the mind plays a central role in Kant's arguments about their proper use. ${ }^{24}$ But Kant also departs from Hume's brand of sensibilism (as well as Locke's and Berkeley's) by recognizing pure intuition as source of a priori sensible representations. And it is this departure that, more than anything else, has created the illusion of a radical discontinuity between Kant and Hume (as well as Kant and the other British Empiricists), where there in fact is great continuity. Waxman's statement of this latter point is quite forceful.

Just as the proverbial flap of a butterfly's wings in Brazil can set off a tornado in Texas when the circumstances requisite to exponentially amplify its force are in place, so too Kant's addition of a thitherto unconsidered source of sensible representations at the inception transforms everything down the line, opening the way to a new conception of fundamental metaphysical concepts, their application to objects a priori, and-for Kant most important of all-a radically new conception of metaphysical freedom. ${ }^{25}$ 
Waxman's view is thus not merely that Kant and Hume have overlapping aims or similar views about the limits of human cognition. This was essentially the point Hamann made in 1781 . Rather, his view is that Hume's and Kant's philosophical outlooks are so fundamentally similar that Kant's philosophy should be viewed as a continuation of Hume's sensibilism and psychologism by non-empirical means and, moreover, that Hume's philosophy would have developed into something recognizable as a version of the critical philosophy, complete with an account of synthetic a priori judgment, had he only recognized the possibility of a priori sensible intuition.

Such is Waxman's reading of Kant's debt to Hume. In my view, however, there are serious difficulties confronting this reading. Specifically, I believe it is difficult (if not impossible) to reconcile with two fundamental aspects of Kant's view in the Critique: the distinction between inner sense and the cognitively inaccessible noumenal self and the equally important distinction between thinking and cognizing (Denken and Erkennen). In the remainder of this section, my goal will be to show that the former distinction is inconsistent with sensibilism, or at least with a sensibilism that can plausibly be attributed to both Kant and Hume, and that the latter is inconsistent with psychologism.

As he develops it in Kant and the Empiricists, Waxman's characterization of sensibilism is ambiguous precisely where it should be most clear. And once this ambiguity is resolved, it becomes clear that Kant is not committed to sensiblism and is, indeed, in one crucial respect radically opposed to it. In particular, when Waxman discusses the importance of internal sense as a source of representations for the sensibilist, it is unclear what the correlate to internal sense is supposed to be in Kant's theory of cognition. By calling it 'internal sense', Waxman suggests that it should be identified with Kantian inner sense, since this is the Kantian notion that comes 
closest to Lockean internal sense, the historical model on which Waxman's notion of internal sense is based. ${ }^{26}$ Moreover, Waxman's characterization of sensibilism as the view that all our representations 'have no existence prior to or independently of their immediate presence to consciousness in perception' also encourages this interpretation, since it is through inner sense that representations are brought to conscious awareness on Kant's account. Finally, in his subsequent treatment of this issue, Waxman explicitly identifies internal sense with Kantian inner sense. ${ }^{27}$

If we interpret internal sense as Kantian inner sense, however, it is false to claim, as Waxman does, that Kant 'counted the mind's perceptions of the operations it performs on the data of sense $[\ldots]$ among the objects of inner [sic] sense'. ${ }^{28}$ To see why this claim is false, we must first ask what the 'data of sense' could amount to on this interpretation. In his exposition of sensibilism, Waxman emphasizes that these include both sensations and reflexions, that is, both the objects immediately present in sense and the mental operations performed on these objects. For Hume, at least in the Enquiry, an example of the former would be the impression of one billiard ball colliding with another, while an example of the latter would be the impression of the 'customary transition' of the imagination from the idea of the first billiard to the idea of the second involved in our judgment that the impact of the first is the cause of the motion of the second. $^{29}$ So the Kantian correlates of these data should be of two types: (a) something immediately present in sense and (b) mental operations on whatever the first kind of thing turns out to be. Further, if Kant is to be a sensibilist, what it is that we are aware of in inner sense would also include the operations of the mind on these data.

Since the introduction of pure sensible intuition is what Waxman regards as the novel element of Kant's alleged sensibilism, one possible interpretation is that the 'data of sense' are 
particular sensible intuitions as well as the operations of the understanding on those intuitions. But if this is the case, then neither type of datum is one of which we are aware at all in inner sense, much less one that serves as the raw material for mental operations of which we are aware. For both particular sensible intuitions and the operations of the understanding on them are what give rise to Kantian inner sense in the first place. As a result, the only sense in which they can be said to be 'among the objects of inner sense' for Kant is incompatible with the sensibilist thesis that these data, like all representations, are immediately available to consciousness. In other words, if we interpret internal sense as Kantian inner sense, a sensibilist reading of Kant commits him to the view that we are aware of particular sensible intuitions prior to their synthesis in the understanding and the operations of the mind that constitute that synthesis. The former is incompatible with Kant's insistence that there can be no cognition without the synthesizing activity of the understanding. ${ }^{30}$ And the latter is incompatible with this view that this activity is not available to us through inner sense but is instead the action of the cognitively inaccessible noumenal self. ${ }^{31}$

Of course, it is a conclusion of Kant's theory of cognition that the objects of inner sense are the products of the synthesizing activity of the understanding and thus that they are 'tainted' by those operations. And one might object that it is precisely in this sense that those operations should be regarded as 'among the objects of inner sense' on a psychologist reading of Kant. But knowing that they are tainted and being conscious of the operations by which they are tainted are two different things. And while knowledge of the former is consistent with Kant's theory of cognition, it is not sufficient to qualify that theory as sensibilist without vitiating the continuity Waxman identifies between Kant and Hume. For it is a characteristic feature of Hume's theory of cognition (and of Locke's) that it is possible for us to be aware of the operations of the mind 
on the data of sense as such and not merely that some or all the objects of inner sense are products of them. Otherwise, the strategy Hume pursues of tracing our idea of necessary connection back to the impression of 'customary transition' in the imagination would not be open to him. Thus, the cost of accepting knowledge that objects of inner sense are the product of operations of the mind as knowledge of those operations in a reading of Kant is that those operations cannot be 'among' the objects of inner sense for Kant in the same way that they are for Hume. ${ }^{32}$

Since psychologism presupposes sensibilism, any reason to resist the claim that Kant is committed to sensibilism is a fortiori a reason to resist the claim that he is committed to psychologism. But there are independent reasons for resisting this narrower claim as well. In particular, psychologism is too coarse-grained to capture Kant's distinction between thinking and cognizing. In order to cognize an object for Kant, it is necessary that the object conform to the conditions of possible experience. That is, it must be an object in space and time subject to the categories. Merely to think an object, in contrast, requires only that the object not violate the law of non-contradiction, that is, that the predicates that jointly define it not contain a contradiction. ${ }^{33}$ However, both thinking and cognition involve the use of the categories. And it is with respect to this point that Waxman's psychologism seems a poor fit for Kant. It is crucial to both Kant's practical philosophy and his account of the regulative use of reason that human freedom, God, and the soul can all be objects of thought and, hence, that the categories used in thoughts about these objects have a legitimate transcendent use, albeit one that does not amount to cognition. ${ }^{34}$ But Waxman suggests in a number of places that, according to psychologism, the use of psychologically tainted representations like the categories to describe mind-independent objects 
is not only illegitimate but absurd. As a result, psychologism appears unable to accommodate a distinction that is central to many of Kant's aims in the Critique.

The incompatibility of psychologism with what Kant elsewhere calls the 'transcendental significance' of the categories is implicit in Waxman's characterization of psychologism (A248/B305). Limiting a representation's domain of application to the 'purview of the experiencing mind' in the same sense that 'pleasures and pains', as subjective contents, are so limited requires us to regard the illegitimate uses of these representations as on a par with claims about unfelt pain, joy, or hate, all of which are not merely false but actually contradictory. ${ }^{35}$ Waxman also draws this conclusion explicitly in his discussion of Kant and Hume. Thus, in connection with Hume's account of causation, he writes that 'Humean psychologistic analysis converts the absurdity concealed in the supposition that "causes may exist independently of thought" into the patent nonsense that "customs of thought may exist independently of thought". ${ }^{36}$ And in discussing the categories, he writes that Kant's account of their origin 'leads straight to the psychologistic conclusion that we contradict ourselves, and talk without meaning', when we attempt to apply the categories 'to objects in contexts where there is, and can be, no consciousness of the act of the synthesis in imagination of a manifold offered by sensibility in accordance with its (ineluctable) subjective constitution' ${ }^{37}$ Thus, psychologism leaves no room for a legitimate extra-psychological use of psychologically tainted representations and, as such, no room for the legitimate, transcendental but non-cognitive use of the categories that is presupposed by Kant's attempt to show the compatibility of noumenal freedom and natural necessity, the regulative uses of the ideas of reason, and the moral argument for the existence of God and immortality of the soul. ${ }^{38}$ 


\section{Hume And TRAnSCEndent Metaphysics}

Without significant revision, then, I think that we should reject Waxman's reading of Kant's debt to Hume. For regardless of whether Hume's doctrines commit to him to sensibilism or psychologism - a question I have not examined here - many of the central views of the Critique suggest that Kant is committed to neither. And if this is true, Kant's debt to Hume cannot be the adoption of sensibilism and psychologism as Waxman suggests. Nevertheless, it is clear from many of Kant's explicit comments about Hume that he credits him with having anticipated and influenced his views in the Critique. So Waxman is certainly right to claim that Hume contributed to the development of the critical philosophy above and beyond his wellknown concerns about causation and, moreover, that this contribution is positive. Otherwise, it is simply inexplicable why Kant praises Hume's philosophy in the ways he frequently does. After discussing the evidence that leads me to believe a positive Humean influence on the critical philosophy is undeniable, I will proceed to argue that this influence consists in Hume's being the first to argue that an analysis of the mind and the sources of its representations can yield strong arguments against rationalist claims to cognition of supersensible objects and that Kant regards this analysis as an important forerunner of his arguments in the Critique.

Evidence of Hume's positive influence on Kant is spread throughout the critical period. In the Preface to the Prolegomena, Kant comments that the only philosophy he found useful as he developed the 'new science' of the Critique was 'the hint that Hume's doubts had been able to

give' (4:262). ${ }^{39}$ Similarly, in the B-Critique, Kant comments that Hume came the closest of all philosophers to identifying the crucial question whose answer will settle the possibility of metaphysics: How are synthetic a priori cognitions possible (B19)? And when Kant tells us in the second Critique that it is Hume who 'can be said to have really begun all the assaults on the 
rights of pure reason', he is implicitly characterizing his own assault on pure reason as a development of Hume's (5:50). What is only implicit in the second Critique becomes explicit in the posthumously published What Real Progress Has Metaphysics Made in Germany Since the Time of Leibniz and Wolff?, where Kant discusses Hume's views on causation under the heading 'History of Transcendental Philosophy among Us in Recent Times' (20:265-6). ${ }^{40}$ In the Metaphysic Mongrovius, Kant is even recorded having explicitly said that 'something similar to a critique of pure reason was found with David Hume' (29:782). ${ }^{41}$ These comments are difficult to read as anything other than an admission that Hume's views were a positive influence on the development of the Critique.

What Kant believed this influence to be becomes clear when we examine his discussions of Hume's views in more detail. For Kant consistently characterizes Hume's project as, first and foremost, an attempt to undermine rationalist claims to cognition of supersensible objects. ${ }^{42}$ That is, although Hume's specific targets were certainly different from Kant's, Kant believes that Hume's primary aim was, like his own, to undermine the possibility of transcendent metaphysics. ${ }^{43}$ Characterizations of Hume's aims in these terms are found in passages from the first Critique, Prolegomena, and second Critique, which I now discuss in turn.

Kant's most extensive discussion of Hume in the first Critique is in the 'Discipline of Pure Reason', the first and longest part of the 'Doctrine of Method'. The Discipline contains Kant's final word on his critique of Wolffian special metaphysics (the sub-discipline of Wolffian philosophy concerned with the existence and nature of God, the soul, and the world in its totality). So it is natural that he also use this part of the Critique to reflect on the advantages his critique has over similar efforts to expose the futility of rationalist attempts to cognize supersensible objects. For this reason, it is significant that the approach he chooses to contrast 
with his own is Hume's (A764/B792). Elaborating on the specific problems Kant identifies would take us too far afield. ${ }^{44}$ But his general conclusion is that Hume's response to rationalism is inferior to his own because Hume does not provide an effective means to counteract reason's natural tendency to overstep its proper bounds. ${ }^{45}$ Kant claims that reason is 'annoyed here and there' by Hume's arguments but that its 'entirely peculiar momentum is not in the least disturbed, but only hindered' by them (A768/B796). ${ }^{46}$ Put in less Kantian terms, Kant's claim is that Hume's arguments are effective against some arguments that purport to establish cognition of supersensible objects like God and the soul but that they lack the comprehensiveness needed to undermine all such arguments. Such comprehensiveness, he believes, can only be found in a critique of our cognitive faculties and, in particular, in a critique of reason. In the first Critique, then, Kant describes Hume's project as one whose aim is essentially the same as his own.

Similar descriptions can be found in the second Critique and Prolegomena. In the former, Kant again describes Hume's project as the attempt to undermine claims to cognition of supersensible objects. After criticizing Feder's attempt in Über Raum und Causalität to show that 'there is and can be no a priori cognition at all', Kant comments that Hume would have been completely satisfied with this 'empiricism in principles' because he:

asked nothing more than that a merely subjective meaning of necessity, namely custom, be assumed in place of any objective meaning of necessity in the concept of cause, so as to deny reason any judgment about God, freedom, and immortality. $(5: 12-3)^{47}$

Two things are significant about this passage. The first is that Kant lists at least two and, arguably, three of the objects of special metaphysics as ones that Hume intends to show we cannot cognize. ${ }^{48}$ The second is that Kant characterizes Hume's desire to show that cognition of these supersensible objects is impossible as the motivation for his account of causation. Kant's reading of Hume's aims in the Enquiry (the text of Hume's with which he was the most familiar) 
is thus the somewhat unorthodox one that Hume does not ask us to accept his deflationary account of the meaning of necessary connection and the nature of causal inference for its own sake or, as one might well think, because of his interest in developing a naturalistic science of man, but 'so as to deny reason any judgment about God, freedom, and immortality'. 49

In the Prolegomena, Kant's views are no different. In an understudied footnote in the Preface, Kant describes Hume as someone who wants to end the 'many endless and continual conflicts that perplex the human species' by curbing the 'excessive claims of speculative reason' (4:259). In $\S 58$, he then identifies the principle 'not to drive the use of reason dogmatically beyond the field of possible experience' as 'Hume's principle' (4:360). Scarcely one page later, he proceeds to describe a very similar principle as the 'result of the entire Critique' (4:361). This principle, the core message of the Critique, is 'that reason, through all its a priori principles, never teaches us about anything more than objects of possible experience alone, and of these, nothing more than what can be cognized in experience' $(4: 360){ }^{50}$ These passages together with those from the first and second Critique we previously considered make clear that Kant consistently thought of Hume's project as an attempt to show that reason and our mental faculties more generally are not equipped to give us knowledge of supersensible objects.

To be sure, this is a somewhat idiosyncratic characterization of Hume's project, if for no other reason than because, as I have already suggested, it abstracts completely from Hume's commitment to naturalism. ${ }^{51}$ Nevertheless, Kant is certainly right to think that Hume wants to deny cognition of supersensible objects like God and the soul. Indeed, claims about God and the soul are the most paradigmatic examples of the 'divinity and school metaphysics' Hume urges us to commit to the flames in the closing paragraph of the Enquiry. ${ }^{52}$ And to this extent, Kant is certainly right to regard Hume as a forerunner. Moreover, as far as I can tell, Hume is also the 
only person prior to Kant who used an analysis of the mind to argue for a blanket denial of our ability to cognize supersensible objects. Certainly, neither Locke nor Berkeley beat him to the punch. $^{53}$ And while materialists like Hobbes and La Mettrie preceded Hume in such a denial, their reasons for doing so were independent of their accounts of the mind and its abilities. ${ }^{54}$ For them, supersensible objects (in the sense of nonmaterial ones) simply did not exist. So there could be no question about whether our minds were suited to cognize them. As a result, Hume's views on the limits of human cognition position him uniquely for the praise Kant gives him in the passages from the first Critique, Prolegomena, second Critique, and Metaphysic Mongrovius we considered a moment ago. And it is in his use of an analysis of the mind to justify his denial of our ability to cognize supersensible objects that I suggest Kant's primary debt to Hume consists.

But if I am right, which arguments did Kant believe Hume used to justify this denial? Elsewhere I have argued that early versions of the Transcendental Dialectic made use of a method for identifying illicit metaphysical claims that Kant associated with Hume and that this method is assigned a lesser but still important role in the published version of the Dialectic. ${ }^{55}$ But if we limit ourselves to Kant's explicit comments about Hume, the obvious answer is Hume's account of causation. After describing Hume's attack on metaphysics as the most important 'since the rise of metaphysics as far as its history reaches' in the Prolegomena, Kant elaborates on the nature of this attack in the following way:

Hume started mainly from a single but important concept in metaphysics, namely, that of the connection of cause and effect (and of course also its derivative concepts, of force and action, etc.) and called upon reason, which pretends to have generated this concept in her womb, to give him an account of by what right she thinks: that something could be so constituted that, if it is posited, something else necessarily must thereby be posited as well; for that is what the concept of cause says. (4:257) 
This passage makes reference to two aspects of Hume's account of causation, both of which relate to his analysis of the mind. The first is the analysis of the origin of the concept of necessary connection, which for Hume lies in an impression of the imagination. The second is the principle of causation ('that something $[\ldots]$ must thereby be posited as well') whose validity depends on the result of this analysis. It is not clear from the passage whether Kant is referring to the general causal principle that all events have some cause or a more specific causal principle positing the existence of particular causal laws. ${ }^{56}$ But this question is not relevant for our purposes. What is important is that Kant believes Hume uses the result of this analysis to justify his denial of our ability to cognize supersensible objects. And Kant is careful to emphasize that the question motivating this analysis is whether the concept of cause 'is thought through reason $a$ priori, and in this way has an inner truth independent of all experience, and therefore also a much more widely extended use which is not limited merely to objects of experience' (4:259). ${ }^{57}$ As Kant understands Hume, then, his main concern is to determine whether the concept of cause has a legitimate supersensible use, and he believes that the proper way to do this is to determine whether it is generated by reason. ${ }^{58}$

Kant attributes the same strategy to Hume in both editions of the first Critique. Before discussing his reasons for believing that Hume's attempt to undermine rationalist claims to cognition of supersensible objects lacks the comprehensiveness of his own, Kant gives a brief description of Hume's arguments:

He [i.e. Hume] dwelt primarily on the principle of causality, and quite rightly remarked about that that one could not base its truth (indeed not even the objective validity of the concept of an efficient cause in general) on any insight at all, i.e. a priori cognition, and thus that the authority of this law is not constituted in the least by its necessity, but only by its merely general usefulness in the course of experience and a subjective necessity arising therefrom, which he called custom. Now from the incapacity of reason in general to make use of this principle that goes beyond all experience, he inferred the nullity of all pretensions of reason in general to go beyond the empirical. (A760/B789) 
As in the passage from the Prolegomena, Kant here makes reference to Hume's analysis of the concept of cause and to the 'principle of causality' whose status this analysis forces us to question. Further, he makes it quite clear that Hume uses the results of this analysis to conclude that reason cannot provide cognition of anything 'beyond the empirical' and thus that it cannot provide cognition of supersensible objects. In both the Prolegomena and the Critique, then, Kant credits Hume's analysis of the concept of necessary connection and its origin in the imagination with being the primary means by which Hume attempts to justify his denial of our ability to cognize supersensible objects.

\section{THE LIMITS OF KANT'S DEBT}

But if Kant's debt to Hume consists in his being the first to use an analysis of the mind in this way, the extent of Kant's debt must be very limited. For Kant also believes that this analysis is fundamentally flawed. He is unequivocal in his rejection of the positive phase of Hume's account of causation. ${ }^{59}$ And as we saw in the previous section, he also believes that Hume's attempt to limit cognition to the empirical by means of the arguments in the negative phase of this account lacks the comprehensiveness of his own attempt in the Critique and that Hume is, for this reason, able only to weaken but not eliminate our natural desire to acquire cognition of such objects. On Kant's view, then, Hume's analysis of the mind fails in the one area where he recognizes an overlap between his and Hume's aims.

More importantly, while Kant's aims are similar to Hume's at this level of generality,

they are deeply at odds with them when considered in more detail. For while both Kant and Hume want to show that (theoretical) cognition of supersensible objects is impossible, Kant 
wants to do so in a way that satisfies constraints to which Hume does not feel bound. First, Kant wants his denial of theoretical cognition of supersensible objects to safeguard the possibility of practical cognition of them by undermining the theoretical arguments for materialism, fatalism, atheism, and pantheism that threaten it. Second, Kant wants this denial to be consistent with the body of synthetic a priori cognition he believes we do have. In other words, Kant wants his account of cognition to accomplish two distinct goals. It should demonstrate the illegitimacy of all arguments purporting to demonstrate the materiality of the soul (materialism), the nonexistence of God (atheism), the unrestricted application of the causal law (fatalism), and God's coextension with the physical world (pantheism) in order to eliminate any possible threats to the practical arguments he offers for God's existence, human freedom, and the immortality of the soul. ${ }^{60}$ But it should also provide a convincing account of the substantive a priori claims we are entitled make on purely theoretical grounds.

Attending to these nuances of Kant's aims in the Critique gives us a good idea of what the limits of Hume's positive influence on Kant must be. As Kant understands his project, Hume attempts to accomplish only the first of Kant's goals, but he is ultimately unsuccessful because his arguments lack the comprehensiveness of a critique of reason. Moreover, since he does not recognize a distinction between theoretical and practical cognition, Hume's arguments, even if they were successful, are too coarse-grained to allow for the possibility of the practical arguments for the existence of God, human freedom, and the immortality of the soul that Kant introduces in the Canon of the first Critique and in later works develops in more detail. ${ }^{61}$ Kant acknowledges the first shortcoming in the passages from the Discipline I discussed at the outset of the previous section, and he acknowledges the second in the continuation of the footnote in the Prolegomena I discussed there as well. After praising Hume's attempt to curb the 'excessive 
claims of speculative reason', Kant proceeds to criticize him for losing sight 'of the positive harm that results if reason is deprived of the most important vistas, from which alone it can stake out for the will the highest goal of all the will's endeavors' (4:258). This second criticism is also implicit in Kant's discussion of Hume in the second Critique, since he there contrasts Hume's attempt to 'deny reason any judgment about God, freedom, and immortality' with his attempt to establish the existence of God, human freedom, and the immortality of the soul as postulates of pure practical reason (5:12-3).

As for Kant's second goal, that of explaining the possibility of the synthetic a priori theoretical cognition we do possess, he makes clear in a number of passages that Hume's account of causation commits him to the denial of synthetic a priori cognition. A version of this criticism appears in the Prolegomena. ${ }^{62}$ But Kant's first and clearest statement of it is in the Discipline of the first Critique. After commenting that Hume may have recognized something like his conception of synthetic a priori judgment, Kant emphasizes the importance of distinguishing between the genuine synthetic a priori judgments of the understanding and the merely putative synthetic a priori judgments of reason.

Hume perhaps had it in mind, although he never fully developed it, that in judgments of a certain kind we go beyond our concept of the object. I have called this sort of judgment synthetic. There is no difficulty about how, by means of experience, I can go beyond the concepts that I possess thus far [...] But we also believe ourselves to be able to go beyond our concept a priori and to amplify our cognition. We attempt to do this either through pure understanding, with regard to that which can at least be an object of experience, or even through pure reason, with regard to such properties of things, or even with regard to the existence of such objects, that can never come forth in experience. (A764-5/B792-3)

Kant then proceeds to contrast his own view with Hume's and to emphasize that, in contrast to the important but limited extent to which he believes we are able to amplify our concepts $a$ priori, Hume denies synthetic a priori cognition tout court: 
Our skeptic [i.e. Hume] did not distinguish these two kinds of judgments, as he should have, and for that reason held this augmentation of concepts out of themselves and the parthenogenesis, so to speak, of our understanding (together with reason), without impregnation by experience, to be impossible; thus he held all of its supposedly a priori principles to be merely imagined, and found that they are nothing but a custom arising from experience and its laws, thus are merely empirical, i.e., intrinsically contingent rules, to which we ascribe a supposed necessity and universality. (A765/B793)

The suggestion that Hume denies synthetic a priori cognition because he does not distinguish between judgments of reason and judgments of the understanding is intriguing. It suggests that this distinction lies at the heart of Kant's own understanding of the fundamental differences between himself and Hume. But the relevant point for our purposes is Kant's comment that Hume regards the a priori 'augmentation of concepts [...] to be impossible', since it is this augmentation that distinguishes synthetic a priori judgments from analytic ones. ${ }^{63}$

At this point, one will have no doubt noticed a similarity between Kant's criticisms of Hume and the objections to Waxman's reading of Kant's debt to Hume that I raised in section one. Just as Kant criticizes Hume for overlooking the importance of limiting speculative reason in a way that also makes room for the possibility of practical arguments for God, freedom, and the immortality of the soul, I have argued that psychologism is too coarse-grained to accommodate the distinction between thought and cognition on which these and other of Kant's arguments in the Critique rest. In my view, this similarity is no accident. For the differences between Kant and Hume to which Kant draws our attention are among those that Waxman's reading obscures. As I suggested in section one, the cost of reading Kant as a psychologist sensu Waxman is to neglect the way in which the arguments of the Critique ultimately serve the ends of his moral philosophy. As we have seen, this is one of the respects in which, despite all of his praise, Kant explicitly distinguishes himself from Hume. Moreover, we have also seen that the 
cost of reading Kant as a sensibilist is to overlook one of the most profound differences between his account of cognition and those of his empiricist predecessors: the conviction that inner sense is something whose distinctive features are the products of operations of the mind that are ultimately inaccessible to us. For these reasons, I believe that Kant's debt to Hume is limited to the relatively modest influence I have described in section two. Hume was the first to use an analysis of the mind and the sources of its representations to provide strong arguments against our ability to cognize supersensible objects. And while Kant ultimately rejected these arguments for the reasons I have noted, he still believed it appropriate to credit Hume with having 'struck a spark' in the field of metaphysics and with having helped him develop his own ideas in the Critique $(4: 257,262)$. This debt is, I have argued, neither as profound nor as far reaching as the debt Waxman attributes to Hume. But in drawing attention to it and its limitations, I hope to have made clear that Kant's relationship to Hume is not only nuanced, which Waxman would certainly grant, but also deeply ambivalent.

Further, this ambivalence provides at least a partial explanation for the consistent appeal of the two very different readings of Kant's relationship to Hume that I sketched in the introduction. If we remain at a certain level of generality, Kant's and Hume's aims overlap. And in many of his comments about Hume, especially in the Prolegomena and the second Critique, Kant does just this. Some have interpreted this overlap as an indication that Kant regarded Hume as essentially an ally and thus that, apart from the further question of whether Kant has any arguments at his disposal that are up to the task, refuting Hume's account of causation was not among Kant's goals in the Critique. ${ }^{64}$ But Kant's repeated insistence that Hume's account of causation is incompatible with the possibility of practical arguments for God, freedom, and the immortality of the soul and tantamount to a denial of synthetic a priori cognition suggests two 
senses in which refuting this account is central to Kant's goals in the Critique. Depending on where one looks, there is thus ample reason to think that Kant regarded Hume's philosophy as a cautionary tale and as a forerunner to his own. What I have suggested in this essay is that we should regard it as both. ${ }^{65}$

\footnotetext{
${ }^{\dagger}$ Citations from the Critique of Pure Reason use the standard A/B format to refer to the pages of the first (A) and second (B) editions. Citations from Kant's other works use the volume number and pagination of the Kant's gesammelte Schriften, edited by the Royal Prussian (later German, now Berlin-Brandenburg) Academy of the
} Sciences. 29 vols. (Berlin: Georg Reimer, later Walter de Gruyter, 1900-). Both are given parenthetically. All other citations are given in the endnotes.

${ }^{1}$ See A853/B883. Kant also endorses the main lines of this story at 4:260-1.

${ }^{2}$ See, for example, K. L. Reinhold, Ueber das Fundament des philosophischen Wissens (Jena: Johann Michael Mauke, 1791) and G. E. Schulze, Aenesidemus oder über die Fundamente der von dem Herrn Professor Reinhold in Jena gelieferten Elementarphilosophie (Helmstädt, 1792). For discussion of these and other works by philosophers of this generation, see Karl Ameriks, Kant and the Fate of Autonomy (Cambridge: Cambridge University Press, 2000) and Frederick Beiser The Fate of Reason: German Philosophy from Kant to Fichte (Cambridge: Harvard University Press, 1987), pp. 226-323.

${ }^{3}$ See, for example, F. C. Stäudlin, Geschichte und Geist des Skeptizismus, vol. 2 (Leipzig: Siegfried Lebrecht Crusius, 1794), pp. 283-96; W. G. L. Eberstein, Versuch einer Geschichte der Logik und Metaphysik bei den Deutschen, vol. 2 (Halle: Johann Gottfried Ruff, 1799), pp. 50-3; Kuno Fischer, Immanuel Kant: Entwicklungsgeschichte und System der kritischen Philosophie (Manmhein: Friedrich Zasserman, 1860), pp. 30-9; and Hans Vaihinger, Commentar zu Kants Kritik der reinen Vernunft, vol. 1 (Stuttgart: Spemann, 1881), pp. 3-11.

${ }^{4}$ See Paul Guyer, Knowledge, Reason, and Taste: Kant's Response to Hume (Princeton: Princeton University Press, 2008), pp. 23-70, and Michael Forster, Kant and Skepticism (Princeton: Princeton University Press, 2008), pp. 3-5 and 21-32. I discuss their views in more detail in my 'Skepticism and the Development of the Transcendental Dialectic', British Journal for the History of Philosophy (forthcoming). 
${ }^{5}$ See Johann Georg Hamann, Briefwechsel, ed. W. Ziesemer and A. Henkel, 7 volumes (Wiesbaden: Insel Verlag, 1955), 4:293, 298, and 343. Hamann's comments actually predate the publication of the Critique. He was able to make them because he had obtained advance copies of the signatures of the Critique from Kant's publisher, Hartknoch. The first 30 signatures arrived on April 4, 1781, followed by an additional 18 on April 14, and the remaining signatures, including the Preface and the last 87 pages of the Doctrine of Method, arrived at the beginning of June. See Hamann, Briefwechsel, 4:278, 289, and 305.

${ }^{6}$ Lewis White Beck, 'A Prussian Hume and a Scottish Kant,' in Essays on Kant and Hume (New Haven: Yale University Press, 1978), pp. 111-29, at p. 112.

${ }^{7}$ See Manfred Kuehn, 'Kant's Conception of Hume's Problem', Journal of the History of Philosophy, 21 (1983), 175-93; 'Kant's Transcendental Deduction: A Limited Defense of Hume', in B. Ouden and M. Moen (eds.), New essays on Kant (New York: Peter Lang, 1987), pp. 47-72; 'Kant’s Critique of Hume’s Theory of Faith', in M.A. Steward and J. P. Wright (eds.), Hume and Hume's Connexions (University Park: Pennsylvania State University Press, 1995); Gary Hatfield, 'The Prolegomena and the Critiques of Pure Reason,' in R. P. Horstmann, V. Gerhardt, and R. Schumacher (eds.), Kant und die Berliner Aufklärung (Berlin: de Gruyter, 2001), pp.185-208; 'What Were Kant's Aims in the Deduction?' Philosophical Topics, 31 (2003), pp. 165-98; and Eric Watkins, Kant and the Metaphysics of Causality (New York: Cambridge University Press, 2005), pp. 374-81. Kuehn also provides a useful summary of his view in Kant: A Biography (New York: Cambridge University Press, 2001), pp. 250-69.

${ }^{8}$ See Wayne Waxman, Kant and the Empiricists: Understanding Understanding (New York: Oxford University Press, 2005). Waxman elaborates on aspects of these views in 'Kant's Humean Solution to Hume's Problem', in D. Garber and B. Longuenesse (eds.), Kant and the Early Moderns (Princeton: Princeton University Press, 2008), pp. 179-92. Earlier version of some of the material from Kant and the Empiricists appeared in this journal as 'Kant's Psychologism Part I', Kantian Review 3 (1999), pp. 41-63 and 'Kant's Psychologism Part II', Kantian Review 4 (2000), pp. 74-97.

${ }^{9}$ See Waxman, Kant and the Empiricists, pp. 18-21 and pp. 37-9, and 'Kant's Humean Solution', p. 174.

${ }^{10}$ Although Waxman, Kant and the Empiricists, pp. 6-9 and pp. 86-116, is critical of the view that work in the history of philosophy should be judged by its relevance to current debates, the prevalence of Kantian and Humean views in current debates in a variety of philosophical sub-disciplines obviously makes the suggestion that, but for 
one crucial difference, Hume and Kant would have developed similar philosophical views of more than just historical interest.

${ }^{11}$ One may, of course, claim that Kant's affinities with Hume are not the result of influence. But this is not Waxman's view. See, for example, ibid., p. 22 note 3.

${ }^{12}$ Cf. Waxman, 'Kant's Humean Solution', pp. 174-6.

${ }^{13}$ Waxman, Kant and the Empiricists, p. 3. There is an obvious difficulty in finding a neutral term to denote the various kinds of mental items Hume and Kant recognize, especially one that is not ambiguous between, in the language I am adopting, a representation and its content. In the first section of the Treatise and in Section 2 of the first Enquiry, Hume introduces 'perception' as a general term denoting both impressions and ideas. Waxman uses the distinctively Lockean term 'idea'. Given Kant's antipathy to this broad use of 'idea', however, and his introduction of 'representation' (Vorstellung or repraesentatio) as a genus whose species include intuitions, concepts, and the ideas of reason, I have adapted my terminology to his. See A319-320/B376-377. The result is sometimes infelicitous, but no more so than the other available options.

${ }^{14}$ When contrasting sensibilism with its counterpart, intellectualism, for example, he emphasizes that the 'key difference' between the two is that the former affirms and the latter denies that the operations of the mind make any contribution to the content of our representations. Similarly, Waxman characterization of intellectualism emphasizes that the non-sensible content of representations for the intellectualist is a consequence of these representations existing 'prior to and independently of their being perceived in sensation or reflexion'. SeeWaxman, Kant and the Empiricists, p. 5. Cf. Waxman, 'Kant's Humean Solution', p. 173, for a formulation of sensibilism that refers exclusively to the content of representations.

${ }^{15}$ See John Locke, An Essay Concerning Human Understanding, ed. P.H. Nidditch (Oxford: Clarendon Press, 1979), 2.1.4.

${ }^{16}$ Waxman, Kant and the Empiricists, p. 4.

${ }^{17}$ See ibid., pp. 3-4. Waxman draws a sharp distinction between 'reflexion' and 'reflection'. The former denotes the objects of internal sense I will presently describe, while the latter denotes instances of discursive activity such as conceptualizing, judging, and reasoning. Waxman is not explicit about the relationship between reflexions and reflections. But he seems to think of reflections as more complex cognitive operations performed on and with the 
help of reflexions. Thus, in his discussion of internal sense, Waxman includes forming propositions and forming sequences of propositions (that is, judging and reasoning) among the mind's operations on the objects of inner sense. ${ }^{18}$ Ibid, p. 4. The quoted material in the rest of this paragraph is from this page.

${ }^{19}$ Hume and Kant are the only figures treated in Kant and the Empiricists that Waxman regards as systematically psychologistic. On his view, Locke's affirmation of abstract ideas prevented him from endorsing psychologism; similarly, while Berkeley's rejection of abstraction made the sensible origin of representations relevant to determining their scope, his belief in the unrestricted validity of the principle that everything that begins to exist must have a cause of its existence prevented him from turning Locke's sensibilism into a full-fledged psychologism. See, ibid., pp. 10-12.

${ }^{20}$ Ibid., p. 9

${ }^{21}$ Ibid.

${ }^{22}$ David Hume, Enquiries Concerning Human and Understanding and Concerning the Principles of Morals, ed. L.A. Selby-Bigge and P.H. Nidditch (Oxford: Clarendon Press, 1975), p. 75, and Waxman, 'Kant's Humean Solution', p. 172. Cf. Waxman, Kant and the Empiricists, pp. 9-12.

${ }^{23}$ See, for example B19-20, 4:258-9, 4:262, 4:272-3, 5:50-2, 26:265-6, and 29:282. I return to these passages in section two.

${ }^{24}$ Thus, while Kant certainly rejects Hume's empirical account of the origin of these representations, Waxman believes he was just as concerned as Hume to offer a psychological account of their origins: '[T]here can be no question that he was fully as concerned as Hume to offer psychological accounts of their origins as representations in the mind, and that he did so with the same end in view: determining whether the mind makes essential contributions to the content of these concepts, and, if so, determine their scope of application accordingly' (Waxman, Kant and the Empiricists, p. 25).

${ }^{25}$ Ibid., p. 12. Cf. Waxman, 'Kant’s Humean Solution', p. 174.

${ }^{26}$ Kant first discusses inner sense at A23/B37, where he describes it as something that gives us 'no intuition of the soul itself, as an object' but that is only a 'determinate form, under which the intuition of its inner state is alone possible', and he subsequently elaborates on this description at A33/B49, B68-9 and, especially, at B153-8. What is at issue here, however, is not whether Kant's conception of inner sense is like Locke's conception of internal sense but whether inner sense is the Kantian correlate to sensibilist internal sense as Waxman conceives it. For a 
discussion of the former question, see Béatrice Longuenesse, Kant and the Capacity to Judge (Princeton: Princeton University Press, 1998), pp. 235-240.

${ }^{27}$ Waxman, 'Kant's Humean Solution', p. 173: 'This psychologism, however, premises another doctrine, common to the apriorist Kant no less than the empiricist Hume, which I shall call sensibilism: the thesis that no content of representation preexists its presence to consciousness in perception, whether in sensation or what Kant, Hume, and others termed, alternately, inner sense, internal perception, or reflection: the mind's perception of its ongoing representational activity, particular the operations by whereby it synthesizes new representations from existing ones'.

${ }^{28}$ Waxman, Kant and the Empiricists, p. 4. Waxman clearly means to be talking about internal sense here. The quotation is taken from a paragraph in which he elaborates on the objects of internal sense. The full sentence reads: 'Third, and most important, the British Empiricists and Kant counted the mind's perceptions of the operations it performs on the data of sense (reflexions as well as sensations) among the objects of inner sense: perceiving, reproducing, previous perceptions, remembering; discerning, comparing, separating, combining; considering as one, considering as related without uniting; forming propositions (judgment), forming sequences of propositions (reasoning); willing, assenting, doubting; and so forth'.

${ }^{29}$ Hume, Enquiries, p. 75. Hume's account of our perception of objects, as opposed to mere collections of simple ideas, is more complicated in the Treatise. But in the Enquiry, he speaks freely of objects and seems to grant, at least for the purposes of articulating his account of causal judgment, that we have impressions of objects. See, for example, the pivotal final three paragraphs of Section VII.

${ }^{30}$ See A50-1/B74-5.

${ }^{31}$ Kant does appear to believe that we are conscious of our noumenal selves, but he is clear that this is only a consciousness that we are. More importantly, he explicitly rejects the idea that we are conscious of ourselves as we are, which it seems would be required for the operations of the mind that give rise to inner sense to be among its objects as well (B157). The classic discussion of Kant's conception of inner sense and the relationship between inner sense and the noumenal self is Kemp Smith, A Commentary to Kant's 'Critique of Pure Reason' (London: Macmillan, 1918), pp. 291-8 and pp. 321-31. More recent ones include, Henry Allison, Kant's Transcendental Idealism (New Haven: Yale University Press, 1983), pp. 255-71, and Graham Bird, The Revolutionary Kant (Chicago: Open Court, 2006), pp. 378-86. 
${ }^{32}$ I am grateful to an anonymous reviewer from the journal for comments prompting me to clarify the ideas in this paragraph.

${ }^{33}$ Kant first introduces this distinction in the B-Preface, where he elaborates on it in the following way: 'To cognize an object, it is required that I be able to prove its possibility (whether by the testimony of experience from its actuality or a priori through reason). But I can think whatever I like, as long as I do not contradict myself, i.e. as long as my concept is a possible thought, even if I cannot give any assurance whether or not there is a corresponding object somewhere within the sum total of all possibilities' (Bxxvi).

${ }^{34}$ See Bxxvii-xxx, A532-58/B560-86, A640-2/B668-70, A669-704 /B697-732, and A795-819/B823-47.

${ }^{35}$ Waxman, Kant and the Empiricists, p. 9. See also Waxman, 'Kant's Humean Solution', p. 172, where he draws this conclusion explicitly.

${ }^{36}$ Waxman, Kant and the Empiricists, p. 25 my emphasis.

${ }^{37}$ Ibid., p. 26.

${ }^{38}$ Waxman anticipates a more limited version of this objection in Kant and the Empiricists, p. 28 note 12. After stating that 'a detailed response to this objection will have to await volume II' of his book, which has yet to appear, he suggests that Kant's description of the categories at B128-9 allows for the possibility that they might be given 'transcendental content' in a way other than the way in which this is done in the Metaphysical Deduction and that this possibility is sufficient to render the concept of noumenal freedom consistent with Kant's alleged commitment to psychologism. Without wanting to pass judgment on arguments Waxman has yet to give, I have two reservations about this strategy as he develops it in the footnote. First, even if it is successful in the case of noumenal freedom and can be generalized to our idea of God, it is not clear how this strategy could be used to account for our regulative use of the transcendental ideas since the alternate way of giving transcendental content to the categories Waxman discusses is only supposed to give them a 'strictly practical' meaning. Second, I do not see how it could be generalized to our idea of God without violating the central tenet of psychologism, since even a concept of God with purely practical content would involve the application of the categories to something independent of our own minds. And however this is done, such an application of the categories for the psychologizer must be as absurd as claims about unfelt pains and joys. While the strategy Waxman outlines may allow him to show that some of Kant's uses of the categories that fall outside of the realm of speculative cognition are compatible with a commitment to psychologism, then, I do not believe it can show that this commitment is compatible with all of them. I hasten to 
add that the importance of the distinction between thought and cognition within the Critique is quite difficult to overstate. In addition to its importance to the practical and regulative uses of reason noted above, it is also crucial to Kant's explanation of why rationalists like Wolff and Baumgarten mistakenly believe that reason can furnish us with cognition of supersensible objects like God and the soul. Kant first discusses the need for this account at B21-22 and develops it in his discussion of transcendental illusion in the introduction and first book of the Transcendental Dialectic.

${ }^{39}$ Immanuel Kant, Prolegomena to Any Future Metaphysics, trans. G. Hatfield, in H. Allison and P. Heath (eds.), Immanuel Kant: Theoretical Philosophy after 1781 (New York: Cambridge University Press, 2002).

${ }^{40}$ Immanuel Kant, What Real Progress Has Metaphysics Made in Germany Since the Time of Leibniz and Wolff?, trans. H. Allison, in H. Allison and P. Heath (eds.), Immanuel Kant: Theoretical Philosophy after 1781 (New York: Cambridge University Press, 2002).

${ }^{41}$ Christoph Mongrovius, Metaphysic Mongrovius, trans. K. Ameriks and S. Naragon, in K. Ameriks and S. Naragon (eds.), Immanuel Kant: Lectures on Metaphysics (New York: Cambridge University Press, 1997). It is worth noting that Kant is also exceedingly complimentary of Hume as a thinker and person. He calls Hume an 'acute man' in the Prolegomena and second Critique (4:277, 5:53). And in the first Critique, Kant describes him as 'cool-headed', 'well-intentioned', 'unblemished in his moral character', 'extremely acute', and 'ingenious' (A7456/B743-4, A760-9/B788-96).

${ }^{42}$ In this respect, I am in broad agreement with the views of Kuehn and Hatfield. See note 7 above.

${ }^{43}$ Recent discussions of the Enquiry are thus in general agreement with Kant on the question of Hume's aims. See Stephen Buckle, Hume's Enlightenment Tract (New York: Oxford University Press, 2001), pp. 27-67, and Peter Millican, 'The Context, Aims, and Structure of Hume's First Enquiry,' in P. Millican (ed.), Reading Hume on Human Understanding (New York: Oxford University Press, 2002), pp. 21-65.

${ }^{44}$ Elaborating on these details is the subject of some work in progress.

${ }^{45}$ For the details on this tendency, which Kant typically refers to as transcendental illusion, see A293-8/B349-55.

${ }^{46}$ Immanuel Kant, Critique of Pure Reason, trans. P. Guyer and A. Wood (New York: Cambridge University Press, 1998).

${ }^{47}$ Immanuel Kant, Critique of Practical Reason, trans. M. J. Gregor, in M. J. Gregor (ed.), Immanuel Kant: Practical Philosophy (New York: Cambridge University Press, 1996). Gregor identifies the reference to Feder at p. 
631 note 3. In what appears to be a typographical error, however, the date given for the publication of Feder's book is 1789 , the year after the second Critique was published. As Gregor was no doubt aware, Feder's book was first published in 1787.

${ }^{48}$ God and the soul are clearly identified as two such objects, and the mention of freedom in the passage might be interpreted as an oblique reference to the world-whole since for Kant certain questions about human freedom are part of cosmology and thus necessarily involve consideration of the world in its totality. In the context of the passage, it is also clear that Kant means to characterize Hume's views as tantamount to the denial of the practical cognition of these objects as well, a view that Kant will argue against in the course of the second Critique. I return to Kant's objections to the practical implications of Hume's views below.

${ }^{49}$ Kant was aware of the Enquiry at least as early as 1759 and had clearly read it by the early 1770's. Hamann mentioned Hume's views on miracles to Kant in a letter from 1759, and the Blomberg Logic makes explicit reference to Sulzer's German edition of Hume's works, which appeared in 1754-5. According to Hamann's correspondence, Kant also borrowed his translation of Hume's Dialogues on two different occasions in 1780. See Hamann, Briefwechsel, 1:378-380, 4:223, and 4:249 and Blomberg Logic 20:218. In contrast, it is generally supposed that Kant had only limited access to Hume's Treatise. Waxman, Kant and the Empiricists, p. 22 agrees that Kant's access to the Treatise was limited, but his subsequent discussion of Hume makes extensive references to parts of the Treatise that Kant could not have known even on the most generous account of the secondary sources available to him. For discussion of the evidence for and against Kant's access to the Treatise, see Lothar Kreimendahl Kant—Der Durchbruch von 1769 (Köln: Jürgen Dinter, 1990), pp. 15-101.

${ }^{50}$ Kuehn, 'Kant's Transcendental Deduction', pp. 51-3, and Kant: A Biography, pp. 259-61, also draw attention to these passages.

${ }^{51}$ It is worth noting, however, that this neglect of Hume's commitment to naturalism is typical of Kant's discussions of Hume. Apart from the passages I mention here, the clearest evidence of this neglect is Kant's claim in the Prolegomena that Hume would have abandoned his empiricism had he realized it was incompatible with his view that mathematical truths are analytic (4:272-3). This neglect is also typical of the discussions of Hume by many of Kant's contemporaries, on which see my 'Kant and the German Reception of Hume's Account of Causation'.

${ }^{52}$ See Hume, Enquiries, p. 165. Hume also mounts a critique of revealed and natural religion in Sections X and XI of the first Enquiry respectively, the latter of which receives extended treatment in the posthumously published 
Dialogues Concerning Natural Religion. And Hume criticizes the doctrine of the immortality of the soul in the posthumously published essay 'On the Immortality of the Soul'. On Kant's access to these and other of Hume's writings, see Günter Gawlick and Lothar Kreimendahl, Hume in der deutschen Aufklärung: Umrisse einer Rezeptionsgeschichte (Stuttgart-Bad Cannstatt: Frommann-Holzboog, 1987).

${ }^{53}$ Locke describes the aim of the Essay as 'to examine our own Abilities, and see what Objects our Understandings were, or were not fitted to deal with', but he includes God among fit objects. See Locke, Essay, Epistle, par. 3, and 4.10.1-6. And providing arguments for the existence of God and immortality of the soul are among Berkeley's professed goal in both the Principles and Dialogues. See the prefaces to both works in George Berkeley, Philosophical Works, Including the Works on Vision, ed. Michael Ayers (London: Everyman, 1975).

${ }^{54}$ See, for example, Thomas Hobbes, Leviathan, in E. Curley (ed.), Leviathan, with selected variants from the Latin edition of 1668 (Indianapolis: Hackett, 1994), 4.20-1; De Corpore, trans. A.P. Martinich, in A.P. Martinich (ed.), Part I of De Corpore (New York: Abaris Books, 1981) 3.4; and J. O. La Mettrie, Machine Man, trans. A. Thomson, in A. Thomson (ed.), Machine Man and Other Writings (Cambridge: Cambridge University Press, 1996), pp. 5-9 and p. 26.

${ }^{55}$ Chance, 'Skepticism and the Development'.

${ }^{56}$ There is a parallel interpretative question about the nature of the principle Kant means to prove in the Second Analogy. For a recent discussion of the issues involved, see Lanier Anderson, 'Kant on the Apriority of Causal Laws', in M. Heidelberger and F. Stadler (eds.), History of Philosophy of Science: New Trends and Perspectives: Vienna Circle Institute Yearbook, 9 (Dordrecht: Kluwer, 2002), pp. 67-80

${ }^{57}$ Waxman, Kant and the Empiricists, p. 20, cites this passage and some of the surrounding text as evidence of Kant's alleged commitment to psychologism. And in the sentence following the one I have quoted, Kant does indeed say, in speaking of Hume, that once the origin of the concept of cause is determined 'the conditions of its use and the sphere in which it can be valid' would already been given (4:259). On the face of it, however, all this passage suggests is that Kant may have thought of Hume as a psychologist sensu Waxman. But there is no indication that Kant approves of Hume's method or has incorporated it into his arguments in the Critique. And many of Kant's other comments in surrounding passages suggest precisely the opposite conclusion. In the passages immediately preceding this discussion, Kant calls Hume's conclusions 'premature and erroneous'. And in a later one, he emphasizes that he was 'far from listening to him with respect to his conclusions' $(4: 258,260)$. 
${ }^{58}$ This possible legitimate supersensible us is, of course, in addition to the legitimate sensible use of the concept of cause that Kant believed Hume never denied. Had Kant simply written 'independent of experience' in the above quote, one might detect an ambiguity between independence from actual experience and independence from the structure of possible experience secured by space, time, and the categories. Understood in this way, Kant's paraphrase of Hume's question could also be interpreted as a question about the use of the concept of cause within possible experience either in addition to or instead of a question about its supersensible use. But Kant's insistence that Hume asks whether the concept of cause 'has an inner truth independent of all experience' excludes this reading, as does his insistence that what is at issue in Hume's discussion is whether the concept has a use 'which is not limited merely to objects of experience' (4:259, my emphasis).

${ }^{59}$ See note 57 above.

${ }^{60}$ See the passages cited in note 35 and, especially, Bxxvii-xxx

${ }^{61}$ Hume does recognize a distinction in the content of theoretical and moral claims. So there is a trivial sense in which he might be thought to draw this distinction. But he does not recognize a difference in the epistemic status of these claims as Kant does when he contrasts theoretical cognition with rational faith or the postulates of pure practical reason. See Kuehn, 'Kant's Critique of Hume's Theory of Faith' for a more detailed discussion of the theological dimension of Kant's response to Hume.

${ }^{62}$ See $4: 258,277$. In the first passage, Kant claims that Hume's account of causation commits him to the denial of metaphysics. In the second, he claims that Hume's account commits him to the denial of all a priori cognition and, in particular, all synthetic a priori cognition. Since metaphysics is only one of two kinds of synthetic a priori cognition — the other being mathematics—-the first claim is, strictly speaking, not identical to the second.

${ }^{63}$ Cf. A6-9/B10-13.

${ }^{64}$ See Hatfield, 'The Prolegomena and the Critiques of Pure Reason', and Watkins, Kant and the Metaphysics of Causality.

${ }^{65}$ I am grateful to Paul Guyer, Gary Hatfield, Adrienne Martin, and Andrew Roche for comments on earlier versions of this paper and to an anonymous reader from the journal for comments that greatly improved the final version. 